\title{
Korelasi antara Kadar Hemoglobin dengan Status Kognitif pada Pasien Geriatri di RSUP Sanglah
}

\author{
Made Nopriantha ${ }^{1}$, RA Tuty Kuswardhani ${ }^{2}$
}

\footnotetext{
${ }^{1}$ Program Studi Pendidikan Dokter Spesialis Penyakit Dalam Fakultas Kedokteran Universitas Udayana/RSUP Sanglah, Denpasar, Bali, Indonesia ${ }^{2}$ Departemen/KSM Penyakit Dalam Fakultas Kedokteran Universitas Udayana/RSUP Sanglah, Denpasar, Bali, Indonesia

E-Mail : depri_bali@yahoo.com
}

Background: There is evidence of decrease hemoglobin level as long as aging process in elderly. In anemic condition not only influence physical status but also induce cognitive impairment in elderly

Objective : to know correlation between hemoglobin level and cognitive impairment in elderly.

Methods: This is a analytic cross sectional study. Data were derived from medical records of elderly/Geriatric patients (age $\geq 60$ years old) admitted to Internal Medicine Department of Sanglah general Hospital between May to July 2017. Anemia status was defined using clinical criteria (Hemoglobin $<10 \mathrm{gr} / \mathrm{dl}$ ) and cognitive impairment was defined using Mini-Mental State Examination (MMSE) questionnaires. We use pearson test to know correlation between two numeric variable with normal distribution. Statistically significant if $p<0.05$.

Results : Total 78 patient was enrolled in this study consist of $37.4 \%$ male and $52.6 \%$ female. Prevalence of cognitive impairment in elderly was $41 \%$ and there is no statistically different based on age and sex. There is correlation between hemoglobin level and cognitive impairment in elderly ( $r=0.237 ; p=0.037)$. Linear regression analysis show that age and hemoglobin level impact cognitive status in elderly.

Conclusion : There is correlation between hemoglobin level and cognitive impairment in elderly Keywords : hemoglobin, cognitive function, anemia, elderly

Latar Belakang : Pada pasien Geriatri terjadi penurunan kadar hemoglobin seiring pertambahan usia. Pada keadaan anemia akan timbul kondisi hipoksik sehingga akan mempengaruhi tidak hanya fungsi fisik tetapi juga fungsi kognitif. Tujuan : Untuk mengetahui korelasi antara kadar hemoglobin dan status kognitif pada pasien geriatri di RSUP Sanglah Metode: Penelitian ini merupakan analisa potong lintang. Data diambil dari rekam medis pasien Geriatri (umur $\geq 60$ tahun) yang dirawat di RSUP Sanglah dari Mei-Juli 2017. Anemia ditentukan berdasarkan kriteria klinis (hemoglobin $<10 \mathrm{gr} / \mathrm{dl}$ ) dan status kognitif ditentukan berdasarkan Mini-Mental State Examination (MMSE). Uji pearson digunakan untuk mengetahui korelasi antara 2 variabel numerik dengan distribusi normal. Data secara statistik signifikan bila $p$ $<0,05$.

Hasil: Total 78 pasien diikutsertakan dalam penelitian ini dimana memuat $37,4 \%$ pria dan $52,6 \%$ wanita. Prevalensi gangguan kognitif pada pasien geriatri sebesar $41 \%$ dan tidak didapatkan perbedaan signifikan berdasarkan umur dan jenis kelamin. Terdapat korelasi antara kadar hemoglobin dan status kognitif pada pasien geriatric. Uji regresi linear menunjukkan umur dan kadar hemoglobin mempengaruhi status kognitif pada pasien geriatri.

Simpulan: . Terdapat korelasi antara kadar hemoglobin dan status kognitif pada pasien geriatri.

Kata Kunci : hemoglobin, status kognitif, anemia, geriatri

\section{PENDAHULUAN}

Kadar hemoglobin mengalami penurunan seiring dengan pertambahan usia. ${ }^{1}$ Penurunan hemoglobin pada lansia biasanya digunakan sebagai penanda klinis pada penyakit kronis. Beberapa tahun kemudian anemia ternyata digunakan sebagai penanda indikator kesehatan yang lebih kompleks. Anemia dikatakan berhubungan dengan disabilitas fungsional, menurunnya kemampuan otot, penurunan aktivitas fisik, dan meningkatnya risiko frailty., ${ }^{2,3}$ Penelitian lain menunjukkan pasien lansia dengan anemia rentan terjadinya penurunan aktivitas fisik dan risiko jatuh. ${ }^{4}$ Anemia terlihat memiliki dampak yang besar dimana insiden semakin meningkat pada lansia dan menjadi masalah kesehatan yang serius. ${ }^{1}$

Pada kondisi anemia akan mengakibatkan penurunan kapasitas oksigen menuju jaringan sehingga terjadi kondisi hipoksik. ${ }^{5}$ Keadaan hipoksik pada anemia terlihat tidak hanya mempengaruhi fungsi fisik tetapi juga mempengaruhi fungsi 
kognitif, mood dan kualitas hidup pasien lansia. ${ }^{6}$ Anemia ringan dikatakan mengakibatkan penurunan fungsi kognitif pada wanita dengan umur 70-80 tahun. ${ }^{7}$ Selain itu dikatakan terdapat peningkatan risiko demensia pada lansia dengan anemia. ${ }^{5,8}$

Berbagai penelitian sudah dilakukan mengenai hubungan antara anemia dengan fungsi kognitif pada pasien dengan lansia, namun data yang diperoleh masih bersifat inkonsisten dan inkonklusif. Hal inilah yang mendorong peneliti untuk melakukan peneltian mengenai hubungan antara kadar hemoglobin dengan status kognitif pada pada pasien lansia, dimana data diambil dari pasien rawat inap yang dirawat oleh Divisi Geriatri di RSUP Sanglah. Penelitian ini bertujuan untuk mengetahui korelasi antara kadar hemoglobin dan status kognitif pada pasien Geriatri.

\section{METODE}

Penelitian ini merupakan penelitian observasional dengan rancangan potong lintang analitik untuk mengetahui korelasi antara kadar hemoglobin dan status kognitif. Data diambil dari rekam medik pasien Geriatri yang dirawat inap oleh Divisi Geriatri RSUP Sanglah.

Sampel penelitian dipilih dengan cara consecutive random sampling. Kriteria inklusi dipakai pasien berumur lebih dari 60 tahun yang dirawat oleh divisi Geriatri Ilmu Penyakit Dalam FK UNUD/RSUP Sanglah dari bulan Mei sampai Juli 2017. Kriteria eksklusi yang dipakai adalah pasien dengan stroke, demensia, pasien dengan perdarahan akut dan Parkinson.

Data dari rekam medik dikumpulkan memuat informasi mengenai umur, jenis kelamin, diagnosis, status kognitif dan kadar hemoglobin. Kadar hemoglobin diperiksa dengan menggunakan metode Automatic Analyzer (fotometer). Pemeriksaan status kognitif menggunakan kuesioner MiniMental State Examination (MMSE). Setiap item mengandung skor dimana interpretasinya ada 3 yakni norma (skor penapisan 25-30), gangguan kognitif ringan (skor penapisan 20-24), dan gangguan kognitif pasti (skor penapisan $<20$ ).

Analisis statistik dengan menggunakan IBM SPSS Statistik versi 21. Data continues dan berdistribusi normal disajikan dalam bentuk mean \pm SD sedangkan apabila tidak berdistribusi normal disajikan dalam bentuk median dan interquartile interval. Uji normalitas dengan menggunakan uji Kolmogorov-Smirnov. Kemudian untuk data kategorikal disajikan dalam bentuk persentase.

Uji hipotesis dengan menggunakan korelasi pearson untuk mengetahui korelasi antara kadar hemoglobin dengan status kognitif apabila data berdistribusi normal, apabila tidak normal menggunakan uji spearman. Besarnya kekuatan korelasi dilihat dari koefisien korelasi (r).
Analisis multivariat menggunakan regresi logistik untuk menganalisis faktor perancu dalam penelitian ini. Analisa data dilakukan dengan program Statistik Program for Social Sciences v. 21. (SPSS Inc, USA). Tingkat kemaknaan $(\alpha)$ penelitian ini ditetapkan pada nilai probabilitas (p) kurang dari 0,05 dengan interval kepercayaan 95\%.

\section{HASIL}

Total sebanyak 78 pasien ikut serta dalam penelitian ini karakteristik sampel bisa dilihat pada Tabel 1. Dari 78 sampel pria sebanyak $37(37,4 \%)$ dan wanita $41(52,6 \%)$ dengan rentang umur 60-93 tahun.

Tabel 1. Karakteristik sampel

\begin{tabular}{lc}
\hline \multicolumn{1}{c}{ Variabel } & $\mathrm{n}=70$ \\
\hline $\begin{array}{c}\text { Jenis Kelamin, } \mathrm{n}(\%) \\
\text { Pria } \\
\text { Wanita }\end{array}$ & $37(37,4 \%)$ \\
Umur (tahun), mean & $41(52,6 \%)$ \\
MMSE, n (\%) & $70.97 \pm 0,89$ \\
Normal & \\
Gangguan kognitif ringan & $46(59 \%)$ \\
Gangguan kognitif berat & $24(30,8 \%)$ \\
Kadar hemoglobin & $8(10,3 \%)$ \\
\hline
\end{tabular}

Singkatan : MMSE $=$ Mini-Mental State Examination

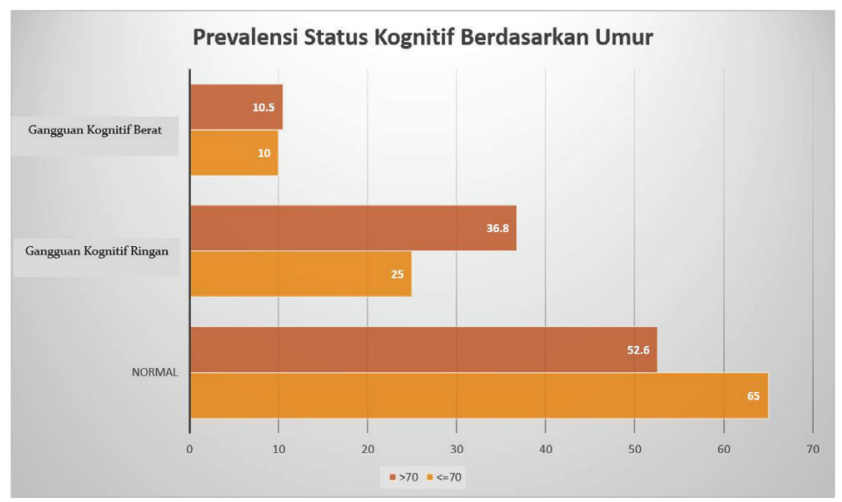

Gambar 1. Prevalensi Status Kognitif Berdasarkan Umur

Prevalensi pasien Geriatri dengan gangguan kognitif sebesar $41 \%$ dimana paling banyak pada umur lebih dari 70 tahun (23\%) dengan jenis kelamin laki-laki (21\%). Namun tidak terdapat perbedaan signifikan berdasarkan umur $(\mathrm{p}=0,379)$ maupun jenis kelamin ( $\mathrm{p}=0,543)$. Pada penelitian ini didapatkan 39,7 \% dengan anemia (hemoglobin $<10 \mathrm{gr} / \mathrm{dl}$ ). 


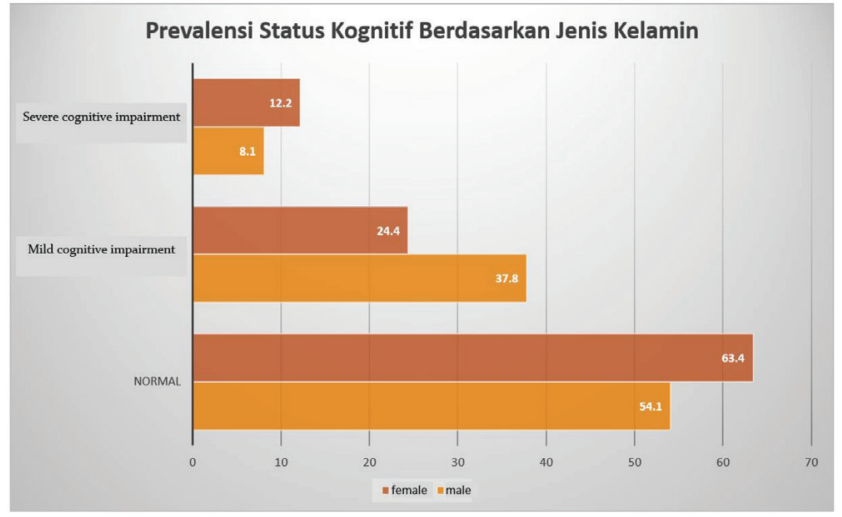

Gambar 2. Prevalensi Status Kognitif Berdasarkan Jenis Kelamin

Korelasi antara kadar hemoglobin dan status kognitif menggunakan uji Pearson karena data berdistribusi normal. Dari uji hipotesis didapatkan koefisien korelasi (r) 0,237 dengan $\mathrm{p}=0,037$ (Tabel 2).

Tabel 2. Hasil Analisis Pearson antara Kadar Hemoglobin dengan Status Kognitif

\begin{tabular}{cc}
\hline & Status Kognitif \\
\hline Kadar Hemoglobin & $\mathrm{r}=0,237$ \\
$\mathrm{p}=0,037$ \\
$\mathrm{n}=78$ \\
\hline
\end{tabular}

Uji korelasi Pearson

Uji regresi linear berganda digunakan untuk menganalisis faktor perancu dari penelitian, dalam hal ini umur dan jenis kelamin. Dari uji statistik didapatkan umur (OR - 0,123 [IK 95\%;-0,228-0,18] p=0,022) dan kadar hemoglobin (OR 0,358 [IK 95\%; 0,067-0,650] p=0,017) secara signfikan mempengaruhi status kognitif pada Geriatri (Tabel 3).

Tabel 3. Faktor Risiko yang Mempengaruhi Status Kognitif Pasien Geriatri

\begin{tabular}{ccc}
\hline Faktor risiko & OR $(95 \%$ CI $)$ & $\mathrm{P}$ \\
\hline Umur & $-0,123(-0,228-, 18)$ & 0,022 \\
Jenis kelamin & $0,530(-1,122-2,161)$ & 0,53 \\
Kadar Hemoglobin & $0,358(0,67-0,65)$ & 0,017 \\
\hline
\end{tabular}

\section{DISKUSI}

Gangguan fungsi kognitif merupakan penyakit terkait usia yang dapat mengakibatkan berbagai masalah kesehatan yakni menimbulkan terjadinya disabilitas bahkan kematian.
Gangguan fungsi kognitif memiliki angka prevalensi yang tinggi pada pasien Geriatri. Gangguan fungsi kognitif tidak hanya mempengaruhi kualitas hidup namun juga memiliki beban sosial ekonomi yang tinggi. ${ }^{9}$

Pada penelitian ini didapatkan prevalensi gangguan kognitif pada Geriatri cukup tinggi yakni 41\% dimana paling banyak pada jenis kelamin laki-laki dan Geriatri yang berumur $>70$ tahun. Angka ini lebih tinggi apabila dibandingkan dengan penelitian dari Emiliano dkk (2011) sebesar 19\% maupun hasil secara global sebesar $14,9 \% .^{10}$ Angka ini dikatakan meningkat seiring dengan pertambahan umur dan menurun sesuai status pendidikan. ${ }^{11}$ Selain itu prevalensi gangguan kognitif dikatakan paling banyak pada wanita terutama tanpa pasangan hidup, dimana hal ini berbeda dari hasil peneliti. Pada wanita dikatakan terdapat penurunan hormone estrogen pada Geriatri yang mempengaruhi fungsi kognitif.'

Korelasi positif $(r=0,237 ; \mathrm{p}=0,037)$ ditemukan antara kadar hemoglobin dan status kognitif pada pasien Geriatri. Hasil ini sesuai dengan penelitian dari Shah dkk (2009) dan Peter dkk (2008).,12 Hal ini menunjukkan bahwa kadar hemoglobin berperan dalam terjadinya gangguan kognitif pada pasien Geriatri. ${ }^{7}$ Ada banyak teori mencoba menjelaskan mekanisme yang mendasari namun dikatakan terdapat 2 mekanisme yakni mekanisme langsung maupun tidak langsung. ${ }^{5}$

Efek langsung anemia pada gangguan kognitif yakni pada kondisi anemia dikatakan terdapat adanya gangguan metabolisme oksidatif di otak. Gangguan metabolisme oksidatif ini mengakibatkan terjadinya peningkatan stress oksidatif dimana mempengaruhi fungsi otak secara langsung sehingga mengakibatkan terjadinya penurunan fungsi kognitif. $^{10}$

Efek tidak langsung anemia pada fungsi kognitif yakni pada kondisi kadar hemoglobin yang rendah terjadi penurunan asupan oksigen ke otak. Dengan penurunan asupan oksigen ke dalam otak maka akan mempengaruhi kemampuan mengingat, kemampuan bekerja dan kecepatan otak untuk berpikir sehingga fungsinya secara umum menjadi terganggu. ${ }^{11}$

Hipotesis lain menyatakan ada peranan zat besi pada penurunan fungsi kognitif. Pada pasien Geriatri dengan anemia juga terjadi penurunan jumlah zat besi dimana sangat diperlukan dalam sel di otak. Penurunan zat besi di otak mengakibatkan penurunan neurotransmitter seperti epinephrine, dopamine dan 5-HT yang diperlukan dalam fungsi kognitif. Ketika terjadi gangguan transmiter mengakibatkan terjadinya hipomielinisasi dan terhambatnya neuromaturasi kemudian mengganggu fungsi kognitif. Selain itu impuls saraf juga dikatakan lebih lambat pada pasien dengan anemia. ${ }^{5}$

Faktor-faktor lain yang mempengaruhi fungsi kognitif 
pada Geriatri yakni berat badan, aktivitas fisik, penggunaan obat antihipertensi dan dislipidemia. Overweight (BMI > 24 $\mathrm{kg} / \mathrm{m}^{2}$ ) dikatakan berhubungan dengan penurunan kognitif sebesar $40 \%$ secara konsisten. ${ }^{13}$ BMI menggambarkan lemak tubuh. Lemak tubuh mempengaruhi metabolisme glukosa dimana metabolism glukosa mempengaruhi fungsi kognitif pada Geriatri. Penjelasan lainnya yakni fungsi kognitif berhubungan dengan status nutrisi, jadi rendahnya lemak tubuh menandakan terjadinya malnutrisi jadi kemungkinan gangguan fungsi kognitif timbul akibat adanya malnutrisi. ${ }^{14}$ Namun pada penelitian ini tidak dilakukan.

Aktivitas fisik dikatakan mengurangi terjadinya penurunan fungsi kognitif pada Geriatri. Beberapa uji klinis menunjukkan Geriatri yang diberikan intervensi berupa latihan fisik secara efektif menurunkan risiko terjadinya gangguan fungsi kognitif. ${ }^{15}$ Ren dkk (2016) menunjukkan pada pasien dengan umur 80 tahun ke atas secara signifikan memperbaiki fungsi kognitif setelah diberikan latihan fisik.? Pada penelitian ini tidak dilakukan penilaian terhadap status nutrisi.

Penggunaan obat antihipertensi dan obat anti dislipidemia dikatakan memberikan efek protektif terhadap fungsi kognitif. Beberapa penelitian masih menunjukkan hasil yang tidak konsisten mengenai hubungan antara serum kolesterol dan penurunan fungsi kognitif. ${ }^{16}$ Secara teori dikatakan pada kondisi hiperkolesterolemia mengakibatkan terjadinya gangguan neurodegeneratif. Metabolismekolesterol abnormal meningkatkan produksi dan deposisi $\beta$-amiloid dalam otak yang mengakibatkan terjadinya gangguan kognitif. Walaupun begitu masih diperlukan banyak penelitian lebih lanjut untuk mengkonfirmasi teori tersebut. ${ }^{9}$

Penelitian menunjukkan penggunaan antihpertensi mengakibatkan penurunan insiden demensia sebesar 50\% pada Geriatri. Pasien dengan terapi antihipertensi secara signifikan memiliki fungsi kognitif lebih baik dibandingkan dengan tanpa terapi. Kontrol tekanan darah yang buruk berhubungan dengan peningkatan risiko terjadinya gangguan kognitif pada pasien dengan terapi hipertensi. Hal ini kemungkinan diakibatkan karena obat antihipertensi menghambat pembentukan lesi pada bagian putih dari otak yang diakibatkan karena hipertensi. ${ }^{8}$

Adapun keterbatasan dalam penelitian ini adalah penelitian ini menggunakan metode potong lintang sehingga tidak menentukan secara jelas faktor risiko yang mempengaruhi fungsi kognitif. Selain itu diperlukan suatu penelitian longitudinal yang memuat variabel lebih banyak sehingga sehingga dapat menjelaskan bagaimana hubungan antara kadar hemoglobin dengan fungsi kognitif beserta faktor perancu lainnya.

\section{SIMPULAN}

Terdapat korelasi positif lemah antara kadar hemoglobin dan status kognitif pada pasien Geriatri.

\section{DAFTAR PUSTAKA}

1. Lucca U, Tettamanti M, Mosconi P, dkk. Association of mild anemia with cognitive, functional, mood and quality of life outcomes in the elderly: the "Health and Anemia" study. PLoS One. 2008;3(4):e1920.

2. Chaves $P H$, Semba RD, Leng SX, dkk. Impact of anemia and cardiovascular disease on frailty status of community-dwelling older women: the Women's Health and Aging Studies I and II. The Journals of Gerontology Series A: Biological Sciences and Medical Sciences. 2005;60(6):729-35.

3. Peters R, Burch L, Warner J, dkk. Haemoglobin, anaemia, dementia and cognitive decline in the elderly, a systematic review. BMC geriatrics. 2008;8(1):18.

4. Penninx BW, Pluijm SM, Lips P, dkk. Late-life anemia is associated with increased risk of recurrent falls. Journal of the American Geriatrics Society. 2005;53(12):2106-11.

5. Ranjan A, Jyothi Y, Das K, dkk. Effects of Anemia on Cognitive Function. Journal of Pharmaceutical Research. 2017;16(2):134-42.

6. Payne CF, Davies JI, Gomez-Olive FX, dkk. Cross-sectional relationship between haemoglobin concentration and measures of physical and cognitive function in an older rural South African population. J Epidemiol Community Health. 2018:jech-2018-210449.

7. Macedo BG, Dias PP, Camara HS, dkk. Anemia in the Elderly: Neuropsychiatric Repercussions. Advances in Aging Research. 2016;6(01):11.

8. Schneider AL, Jonassaint C, Sharrett AR, dkk. Hemoglobin, anemia, and cognitive function: the Atherosclerosis Risk in Communities Study. Journals of Gerontology Series A: Biomedical Sciences and Medical Sciences. 2015;71(6):772-9.

9. Ren L, Zheng Y, Wu L, dkk. Investigation of the prevalence of Cognitive Impairment and its risk factors within the elderly population in Shanghai, China. Scientific reports. 2018;8(1):3575.

10. Rodríguez-Sánchez E, Mora-Simón S, Patino-Alonso MC, dkk. Prevalence of cognitive impairment in individuals aged over 65 in an urban area: DERIVA study. BMC neurology. 2011;11(1):147.

11. Ankri J, Poupard M. Prevalence and incidence of dementia among the very old. Review of the literature. Revue d'epidemiologie et de sante publique. 2003;51(3):349-60.

12. Shah RC, Wilson RS, Tang Y, dkk. Relation of hemoglobin to level of cognitive function in older persons. Neuroepidemiology. 2009;32(1):40-6.

13. Dahl AK, Löppönen M, Isoaho R, dkk. Overweight and Obesity in Old Age Are Not Associated with Greater Dementia Risk: (See editorial comments by Dr. David S. Knodman, pp 2349-2350). Journal of the American Geriatrics Society. 2008;56(12):2261-6.

14. Guallar-Castillón P, Balboa-Castillo T, López-García E, dkk. BMI, waist circumference, and mortality according to health status in the older adult population of Spain. Obesity. 2009;17(12):2232-8.

15. Yang S-Y, Shan C-L, Qing H, dkk. The effects of aerobic exercise on cognitive function of Alzheimer's disease patients. CNS \& Neurological Disorders-Drug Targets (Formerly Current Drug Targets-CNS \& Neurological Disorders). 2015;14(10):1292-7.

16. Lv Y-B, Yin Z-X, Chei C-L, dkk. Serum cholesterol levels within the high normal range are associated with better cognitive performance among Chinese elderly. The journal of nutrition, health \& aging. 2016;20(3):280-7.

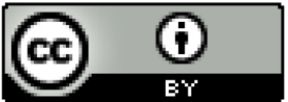

This work is licensed under a

Creative Commons Attribution 4.0 International License. 